\title{
Study on the antibacterial activity of selected natural herbs and their application in water treatment
}

\section{P. S. Harikumar and C. M. Manjusha}

Water Quality Division, Centre for Water Resource Development and Management, Kozhikode-673571, Kerala, India

Received: 18 July 2013 - Accepted: 3 August 2013 - Published: 22 August 2013

Correspondence to: P. S. Harikumar (hps@cwrdm.org)

Published by Copernicus Publications on behalf of the Delft University of Technology.

\section{Antibacterial activity of selected natural herbs \\ P. S. Harikumar and \\ C. M. Manjusha}

\section{Title Page}

\section{Full Screen / Esc}




\section{Abstract}

The microbial contamination of water is a world-wide environmental problem. Many traditional methods are being used in various parts of the world to purify the water. According to World Health Organization, $80 \%$ of world's population living in rural areas 5 relies on herbal traditional medicines as their primary health care. So the study on properties and uses of medicinal plants are subject to growing interests. An attempt was made to assess the antibacterial properties of certain selected herbs such as Ocimum sanctum (Krishna Tulsi), Ocimum kilimandscharicum (Karpoora Tulsi), Ocimum tenuiflorum (Ram Tulsi), Azadirachta indica (Neem), Simarouba glauca (bitterwood), Cae(Rama sappan (Pathimugam), Cuminum cyminum (Jeerakam), Vetiveria zizanioides (Ramacham), Saraca indica (Ashoka tree) and Murraya koenigii (curry leaves) against different bacteria such as total coliforms, faecal coliforms, Escherichia coli, Bacillus $\mathrm{sp}$. and Serratia sp. The antibacterial activity of the plant extracts was determined by spread plate method, Kirby-Bauer disc diffusion method, most probable number (MPN) method and Petrifilm method. The shelf life of the herbal extract Ocimum sanctum (Krishna Tulsi) was also determined using a UV-visible spectrophotometer. A comparison study of the antibacterial efficiency of the three varieties of Ocimum sanctum, Ocimum kilimandscharicum and Ocimum tenuiflorum was also done. After the complete analysis of the antibacterial activity of different herbs, Ocimum sanctum, the most efficient herb, was selected and treatment methods based on the herb were developed so that it can be used conveniently in various households. Therefore Ocimum sanctum plant can be further subjected to isolation of therapeutic antimicrobial and pharmacological evaluation.

\section{Introduction}

25 It is a well known fact that most of the chemical disinfectants used for antibacterial activity generate various unwanted chemicals known as disinfections by products (DBPs)
DWESD

6, 199-231, 2013

\section{Antibacterial activity of selected natural herbs \\ P. S. Harikumar and \\ C. M. Manjusha}

Title Page

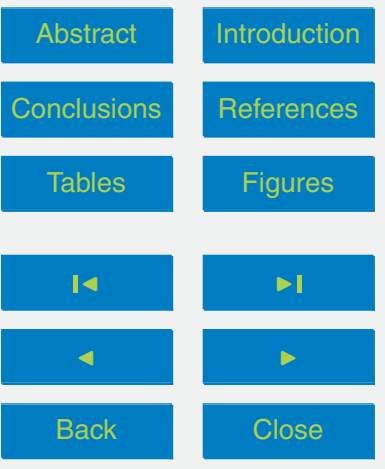

Full Screen / Esc

Printer-friendly Version

Interactive Discussion 
in water. DBPs may cause harmful effects on humans such as hemolytic anemia, cancer risk, nervous system effect and liver effects. Chlorine, which is applied to water at various points in a water treatment for disinfection, combined with naturally occurring organic matter (NOM) to generate DBPs in general and halogenated DBPs is particular

5 (Sunil et al., 2011). Medicinal plants are a source of great economic value all over the world. Nature has bestowed on us a very rich botanical wealth, and a large number of diverse types of plants grow in different parts of the country. Herbal medicine is still the mainstay of about $75-80 \%$ of the whole population, and the major part of traditional therapy involves the use of plant extracts and their active constituents. Nowa10 days multiple-drug resistance has developed due to the indiscriminate use of commercial antimicrobial drugs commonly used in the treatment of infectious disease. In addition to this problem, antibiotics are sometimes associated with adverse effects on the host including hypersensitivity, immunosuppression and allergic reactions. This situation forced scientists to search for new antimicrobial substances. Given the alarming 15 incidence of antibiotic resistance in bacteria of medical importance, there is a constant need for new and effective therapeutic agents. Therefore, there is a need to develop alternative antimicrobial drugs for the treatment of infectious diseases from medicinal plants (Bishnu Joshi et al., 2009).

\section{Methodology}

\subsection{Preparation of different herbal extracts}

The leaves $(20 \mathrm{~g})$ of the various herbs of Ocimum sanctum, Ocimum kilimandscharicum, Ocimum tenuiflorum, Azadirachta indica, Simarouba glauca, Saraca indica, Caesalpinia sappan, Cuminum cyminum, Vetiveria zizanioides and Murraya koenigii were soaked overnight in water, and then they were thoroughly ground using mortar and
DWESD

6, 199-231, 2013

\section{Antibacterial activity of selected natural herbs \\ P. S. Harikumar and \\ C. M. Manjusha}

\section{Title Page}
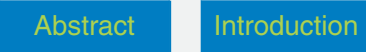

Conclusions

Tables
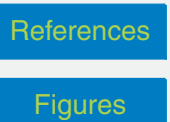

14

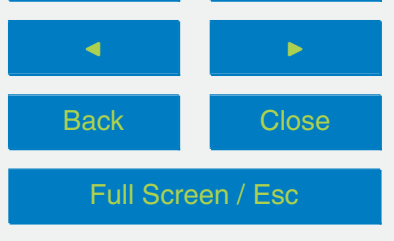

Printer-friendly Version

Interactive Discussion 


\subsection{Assessment of antibacterial activity of different herbal extracts}

The antibacterial activity of different herbal extracts was determined separately using spread plate method (Lansing et al., 2002), Kirby-Bauer disc diffusion method (Harold, 2001), most probable number (MPN) method (APHA, 2012; Lansing et al., 2002), and

5 Petrifilm method (Linton et al., 1997).

\subsubsection{Spread plate method}

Spread plate method was used to detect the initial and final bacterial count of the well water samples before and after the addition of different plant extracts. Then samples were checked for any reduction in the bacterial count; $0.1 \mathrm{~mL}$ pure cultures of microor10 ganisms were uniformly spread on nutrient agar plates using an L-rod. The results were then observed after incubation of $37^{\circ} \mathrm{C}$ for $24 \mathrm{~h}$. Duplicates were also maintained for determining the accuracy of the results.

\subsubsection{Kirby-Bauer disc diffusion method}

In the disc diffusion method, each log phase bacterial inocula of Escherichia coli, Ser15 ratia sp., and Bacillus spp. (100 $\mu \mathrm{L})$ were swabbed onto Petri plates containing $4 \mathrm{~mm}$ thick Müller-Hinton agar respectively and kept for $5 \mathrm{~min}$. Pre-sterilized paper discs that were dipped into different herbal extracts of Ocimum sanctum, Ocimum kilimandscharicum, Ocimum tenuiflorum, Azadirachta indica, Simarouba glauca, Saraca indica, Caesalpinia sappan, Cuminum cyminum, Vetiveria zizanioides and Murraya koenigii were then placed in different microbe-inoculated plates with the help of sterile forceps and incubated at $37^{\circ} \mathrm{C}$ for $24 \mathrm{~h}$. A disc soaked in sterile distilled water acted as the control. Results were analysed by determining the clear zone of inhibition around the discs. Duplicates were also maintained for determining the accuracy of the results. A graph was also plotted by determining the different values measured, and it is given in Fig. 11.
DWESD

$6,199-231,2013$

\section{Antibacterial activity of selected natural herbs \\ P. S. Harikumar and \\ C. M. Manjusha}

\section{Title Page}
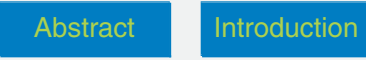

Conclusions
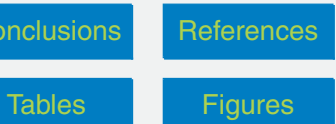

Tables

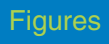

14

4

Back

Full Screen / Esc

Printer-friendly Version

Interactive Discussion 


\subsubsection{Most probable number (MPN) method}

This method helped to detect the reduction in total coliform count, faecal coliform count and Escherichia coli count before and after the addition of varying concentration $(2.5 \mathrm{~mL}, 5 \mathrm{~mL}, 7.5 \mathrm{~mL}, 10 \mathrm{~mL}, 12.5 \mathrm{~mL}$ and $15 \mathrm{~mL})$ of different herbal extracts to

$5100 \mathrm{~mL}$ well water samples. Time duration of $4 \mathrm{~h}$ was maintained after the addition of different herbal extracts to the water samples and then subjected to the analysis using MPN method. In this method, a $10 \mathrm{~mL}$ sample was added to 3 tubes of double-strength MacConkey broth, whereas a $1 \mathrm{~mL}$ and $0.1 \mathrm{~mL}$ sample were added to the first 3 tubes and second 3 tubes of single-strength MacConkey broth respectively. Three loopfuls of positive MacConkey tubes were then used to inoculate onto brilliant green tubes for the detection of faecal coliforms. For the detection of $E$. coli (EC), broth was used as the nutrient medium. The total coliform, faecal coliform and E. coli count can be determined by referring to the MPN index table. Duplicates were also maintained for determining the accuracy of the results. A graph was plotted showing the percentage of removal of total coliforms, faecal coliforms and Escherichia coli in different herbal extracts, and it is given in Figs. 1-10. The percentage of reduction was calculated using the following formula:

Percentage of reduction $=(($ Initial CFU - Final CFU $) /$ Initial CFU $) \cdot 100$.

\subsubsection{Petrifilm method}

In this method the total coliform count and Escherichia coli count were analysed. A total of $1 \mathrm{~mL}$ of sample was added on the Petrifilm and was then spread using a spreader. The results were then observed after incubation of $37^{\circ} \mathrm{C}$ for $24 \mathrm{~h}$. Duplicates were also maintained for determining the accuracy of the results. A graph was also plotted showing the percentage of removal of total coliforms and Escherichia coli, and it is given in Figs. 1-10.
DWESD

6, 199-231, 2013

\section{Antibacterial activity of selected natural herbs \\ P. S. Harikumar and \\ C. M. Manjusha}

Title Page
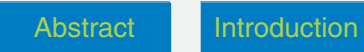

Conclusions

Tables
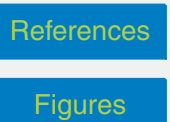

14

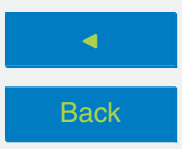

$>1$

Close 
The mean, median and and standard deviation of percentage reduction values of total coliforms, faecal coliforms and E. coli with respect to different herbs were calculated and are shown in Tables 1-3.

\subsection{Determination of the shelf life of different herbal extracts}

5 Shelf life is the duration of time that foods, beverages, pharmaceutical drugs, chemicals, and many other perishable items are given before they are considered unsuitable for sale, use, or consumption. The shelf life of Ocimum sanctum was determined by checking their relatively stable value of absorbance in UV-VIS spectrophotometer at $650 \mathrm{~nm}$. The day till it showed a difference in absorbance value indicated the shelf life of the plant extract. A graph was also plotted showing the absorbance at different days, and it is given in the Fig. 12.

\subsection{Comparison study of the antibacterial efficiency of the three varieties of Ocimum sanctum, Ocimum kilimandscharicum and Ocimum tenuiflorum}

The herb with highest antibacterial activity among the three varieties of Ocimum sanc-

\begin{abstract}
ferent antimicrobial detection tests such as spread plating, MPN method, Kirby-Bauer
\end{abstract} tum, Ocimum kilimandscharicum and Ocimum tenuiflorum was determined after the difdisc diffusion method and Petrifilm method.

\subsection{Introduction of the herbal essence in various households}

After the complete analysis of the antibacterial activity of different herbs, the most ef-

ficient herb identified was introduced in 22 local households to study the perception of the people and the effectiveness of the herbal extract on the removal of pathogenic bacteria. The total coliform count, faecal coliform count and Escherichia coli count before and after the addition of the herbal extract were determined. A quantity of $15 \mathrm{~mL}$ (3 teaspoons) of herbal extract was added to $100 \mathrm{~mL}$ of water samples and was then 25 subjected to bacteriological analysis. The acceptance of herbal extract for treating the
DWESD

6, 199-231, 2013

\section{Antibacterial activity of selected natural herbs \\ P. S. Harikumar and \\ C. M. Manjusha}

Title Page
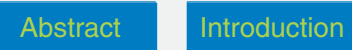

Conclusions

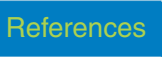

Tables

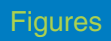

14

4

Back

Full Screen / Esc

Printer-friendly Version

Interactive Discussion
Close 
drinking water source was ascertained through a survey. This monitoring in the selected households helped to check the efficiency of the improved water quality on the health especially reduction in morbidity due to water-borne diseases. The details of sampling stations are shown in Table 4, and the acceptance levels of different house5 holds are shown in Table 5. A graph was also plotted showing the percentage of removal of total coliforms, faecal coliforms and Escherichia coli in the different households and is depicted in Fig. 13.

\section{Result and discussion}

In this present investigation, all the extracts of natural herbs used for the study showed 10 antibacterial activity. In the case of the extracts of Azadirachta indica, Simarouba glauca, Saraca indica, Cuminum cyminum, and Murraya koenigii, no antibacterial activity was shown against Serratia sp. and Bacillus sp. The results of MPN and Petrifilm methods gave similar results. Based on the MPN and spread plate methods, the percentage of removal of E. coli using $15 \mathrm{~mL}$ Ocimum sanctum extract in $100 \mathrm{~mL}$ well water sample was $100 \%$. The percentage reductions of total coliform in the extracts of Ocimum sanctum, Ocimum kilimandscharicum, Ocimum tenuiflorum, Azadirachta indica, Simarouba glauca, Saraca indica, Caesalpinia sappan, Cuminum cyminum, Vetiveria zizanioides and Murraya koenigii were found to be $75.12 \%, 66.68 \%, 62.6 \%, 52.27 \%$, $42.63 \%, 47.7 \%, 54.98 \%, 15.73 \%, 60.22 \%$ and $49.62 \%$ respectively, whereas in $65.12 \%, 55.1 \%, 50.02 \%, 51.92 \%, 59.43 \%, 16.52 \%, 62.38 \%$ and $52.98 \%$ respectively. In the case of $E$. coli, the percentage reductions were $79.47 \%, 75.27 \%, 67.43 \%$, $59.25 \%, 53.23 \%, 55.75 \%, 61.77 \%, 20.97 \%, 64.18 \%$ and $57.38 \%$ respectively in Ocimum sanctum, Ocimum kilimandscharicum, Ocimum tenuiflorum, Azadirachta indica, zizanioides and Murraya koenigii extracts. The shelf life of Ocimum sanctum herbal extract was detected as 16 days. This result showed that the Ocimum sanctum ex-

DWESD

6, 199-231, 2013

\section{Antibacterial activity of selected natural herbs \\ P. S. Harikumar and \\ C. M. Manjusha}

\section{Title Page}
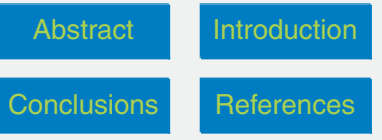

Tables

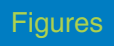

14

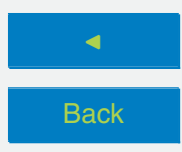

$>1$

$>$

Close 
tract can be considered as a suitable material for use for 16 days, and after that its life ceases.

According to the Kirby-Bauer disc diffusion method, zone of inhibition was shown by all the herbal extracts for E. coli. But in the case of Azadirachta indica, Simarouba 5 glauca, Saraca indica, Cuminum cyminum, and Murraya koenigii, no zone of inhibition was shown against Serratia sp. and Bacillus spp. This showed that there is no antibacterial activity for the extracts of Azadirachta indica, Simarouba glauca, Saraca indica, Cuminum cyminum, and Murraya koenigii against Serratia sp. and Bacillus spp. Highest zone of inhibition was shown by $E$. coli in Ocimum sanctum extract $(2.2 \mathrm{~cm})$. The varia10 tion in antibacterial activity of different herbal extracts against different microorganism may be due to the difference in activity of their chemical constituents against different microorganisms. The major chemical constituents of essential oil of fresh leaves of Ocimum sanctum are eugenol (57.94\%), $\beta$-caryophyllene $(15.32 \%), \beta$-elemene $(7.57 \%)$ and germacrene D (9.10\%) (Mondal et al., 2007). These chemical components may 15 be responsible for the efficiency of the Ocimum sanctum extract in showing the highest antibacterial activity by causing more cell damage in microbes compared to other herbs.

Spread plate method also helped to determine the antibacterial activity of different herbal extracts, and also the results were almost similar to the other methods used. The final colony-forming unit (CFU) tremendously declined compared to the initial CFU in the herbal extracts of Ocimum sanctum, Ocimum kilimandscharicum, Ocimum tenuiflorum, Vetiveria zizanioides and Caesalpinia sappan. Among these extracts Ocimum sanctum showed the highest antibacterial efficiency. In the other extracts also there was variation in CFU but was less compared to Ocimum sanctum, Ocimum kilimandscharicum, Ocimum tenuiflorum, Vetiveria zizanioides and Caesalpinia sappan.

From the comparative study between the extracts of Ocimum sanctum, Ocimum kilimandscharicum and Ocimum tenuiflorum, the Ocimum sanctum extract showed the best antibacterial activity followed by Ocimum kilimandscharicum and then Ocimum tenuiflorum extracts.

\section{DWESD}

6, 199-231, 2013

\section{Antibacterial activity of selected natural herbs \\ P. S. Harikumar and \\ C. M. Manjusha}

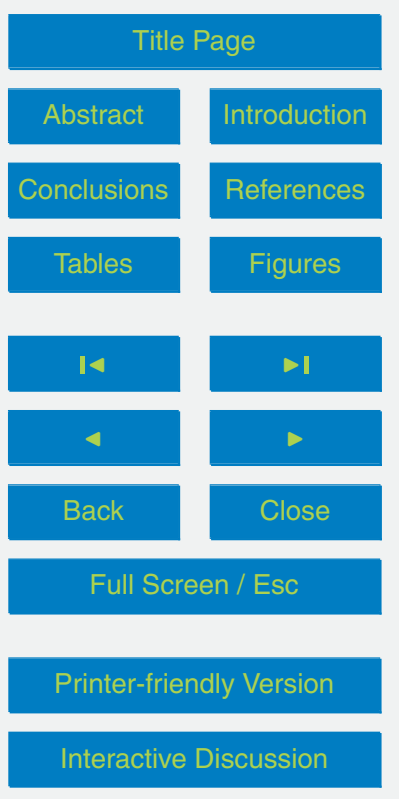


A study was conducted to determine the removal of bacteria in various households after the addition of herbal extract. Out of the 22 samples tested, 9 samples were found to be polluted with E. coli, and all of these 9 samples showed $100 \%$ reduction after the treatment with Ocimum sanctum extract. In the case of faecal coliforms, 12 sam5 ples showed bacteriological pollution with faecal coliforms, and all these 12 samples showed $100 \%$ reduction except in the case of Manakadavu (85.3\%), Madathil $(79.1 \%)$ and Cherinchal $(64.3 \%)$ sampling sites. But in the case of total coliforms, the highest percentage reduction was shown in the sampling site near Markaz School (100\%). This variation in percentage reduction can be attributed to the fact that same cono centration $(15 \mathrm{~mL})$ of Ocimum sanctum extract was added to reduce bacterial load of different concentration from samples taken from different households. Therefore in the case of Manakadavu, Madathil and Cherinchal sampling sites, $15 \mathrm{~mL}$ of herbal extract may not be sufficient to reduce the faecal coliform count to $100 \%$. The initial bacterial load of these sampling sites was also higher compared to other sampling stations. This 15 is similar in the case of total coliforms also.

\section{Significance}

The major significance of the study lies in the cost-effective treatment of faecally contaminated well water samples in various rural households. This can be achieved by using a natural herbal essence of Ocimum sanctum. The treatment is simple, ecofriendly, and reachable for all, and the components present in herbs have no side effects for humans compared to chemical treatments. Moreover, the water treated with these extracts serves both as germ-free and medicinal water. In rural areas the majority of the people are using the water without any treatment. They are also reluctant to use chemicals as disinfectants. Natural herbs used in this study can be effectively used
DWESD

6, 199-231, 2013

\section{Antibacterial activity of selected natural herbs \\ P. S. Harikumar and \\ C. M. Manjusha}

Title Page
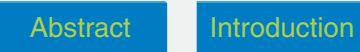

Conclusions

Tables References

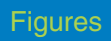

14

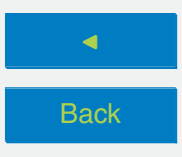

$>1$

$\triangleright$

Close
Full Screen / Esc

Printer-friendly Version

Interactive Discussion 
These findings will support the traditional knowledge of local users, and it will be a preliminary scientific validation for the use of these plants for antibacterial activity to promote proper conservation and sustainable use of such plant resources. Awareness of local community should be enhanced incorporating the traditional knowledge 5 with scientific findings. The results of the present study support the folkloric usage of the studied plants and suggest that some of the plant extracts possess compounds with antimicrobial properties that can be further explored for antimicrobial activity. This antibacterial study of the plant extracts will demonstrate that folk medicine can be as effective as modern medicine to combat pathogenic microorganisms. The millenarian to use of these plants in folk medicine suggests that they represent an economic and safe alternative to treat infectious diseases.

\section{References}

Almas, K.: The antimicrobial effects of extracts of Azadirachta indica (Neem) and Salvadora persica (Arak) chewing sticks, J. Ethnopharmacol., 74, 113-123, 2001.

APHA: Standard Methods for the Examination of Water and Waste Water, 14th Edition, American Public Health Association, American Works Association, Water Environment Federation, 913-918, 1976.

Bishnu, J., Sunil, L., and Anuja, S.: Antibacterial Property of Different Medicinal Plants: Ocimum sanctum, Cinnamomum zeylanicum, Xanthoxylum armatum and Origanum majorana.

20 Journal of Science, Eng. Technol., 5, 143-150, 2009.

Bonde, S. R., Rathod, D. P., Ingle, A. P., Ade, R. B., Gade, A. K., and Rai, M, K.: Murraya koenigii - mediated synthesis of silver nanoparticles and its activity against three human pathogenic bacteria, Nanoscience Methods, 1, 25-36, 2012.

Charusheela Ramteke, Tapan Chakrabarti, Bijaya Ketan Sarahgi and Ram Avatar Pandey: for enhanced bacterial activity, Hindawi Publishing Corporation Journal of Chemistry, 2013, 278925, doi:10.1155/2013/278925, 2012.

DWESD

6, 199-231, 2013
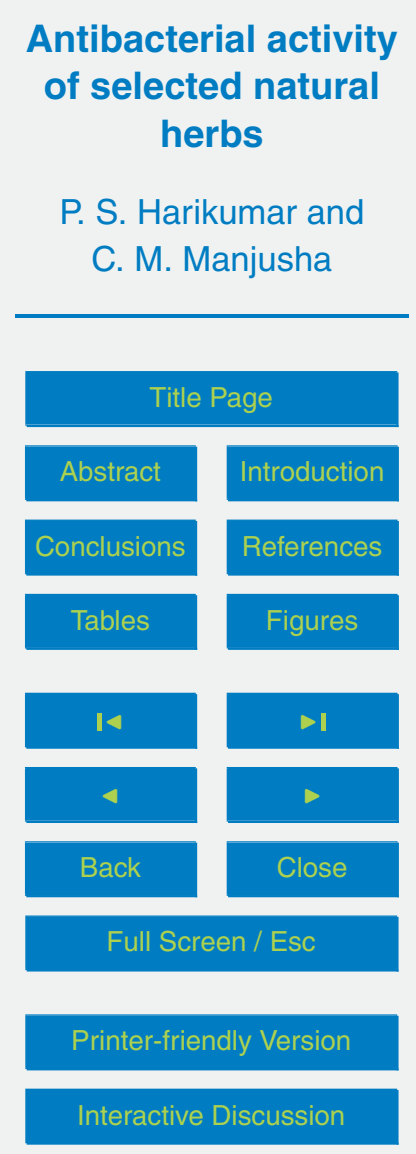

Interactive Discussion 
Clark, A. M. and Hufford, C. D.: Disco and development of novel prototype antibiotics for opportunistic infections related to the acquired immunodeficiency syndrome, Am. Chem. Soc., 534, 228-241, 1993.

Daizy, P. and Unni, C.: Extracellular biosynthesis of gold and silvernanoparticles using Krishna tulsi (Ocimum sanctum) leaf, Physica E, 43, 1318-1322, 2011.

Dorman, H. J. D. and Deans, S. G.: Antimicrobial agents from plants: antibacterial activity of plant volatile oils, J. Appl. Microbiol., 88, 308-316, 2000.

Geeta, Vasudevan DM, Kedlaya, R., Deepa, S., Ballal, M.: Activity of Ocimum sanctum (the traditional Indian medicinal plant) against the enteric pathogens, Indian Journal of Medical

10 Sciences, 55, 434-443, 2001.

Harold, B. J.: Microbiological Application-Laboratory Manual in General Microbiology, 8th Edition, The Mc Graw-Hill Companies 145-147, 222-225, 431, 2001.

Iqbal Ahmad and Arina Beg, Z.: Antimicrobial and phytochemical studies on 45 Indian medicinal plants against multi-drug resistant human pathogens, J. Ethnopharmacol., 74, 113-123,

152001.

Jangale, B. L., Ugale, T. B., Aher, P. S., Toke, N. R., Shivangikar, A. R., and Sanap, N. P.: Antibacterial activity of Simarouba glauca leaf extracts against food borne spoilage and pathogenic microorganisms, International Journal of Pharmaceutical Sciences and Research, 3, 497-500, 2012.

Jigna Parekh and Sumitra Chanda, V.: In vitro Antimicrobial Activity and Phytochemical Analysis of Some Indian Medicinal Plants, Turkish Journal of Biology, 31, 53-58, 2007.

Kiruba Daniel, S. C. G., Kumar, R., Sathish, V., Sivakumar, M., Sunitha, S., and Anitha Sironmani, T.: Green Synthesis (Ocimum tenuiflorum) of Silver Nanoparticles and Toxicity Studies in Zebra Fish (Danio rerio) Model, International Journal of NanoScience and Nanotechnology, 2, 103-117, 2011.

Krishnaraj, C., Jagan, E. G., Rajasekar, S., Selvakumar, P., Kalaichelvan, P. T., and Mohan, N.: Synthesis of silver nanoparticles using Acalypha indica leaf extracts and its antibacterial activity against water borne pathogens, Colloids and Surfaces B, 76, 50-56, 2010.

Lansing, Prescott, M., John, Harley, P., and Donald, Klein, A.: Microbiology, 5th Edition, The Mc Graw-Hill Companies 106-107, 654-655, 2002.

Linton, R. H., Eisel, W. G., and Muriana, P. M.: Comparison of Conventional Plating Methods and Petrifilm for the Recovery of Microorganisms in a Ground Beef Processing Facility, J. Food Protect., 60, 1084-1088, 1997.

\section{DWESD}

6, 199-231, 2013

\section{Antibacterial activity \\ of selected natural herbs \\ P. S. Harikumar and \\ C. M. Manjusha}

\section{Title Page}
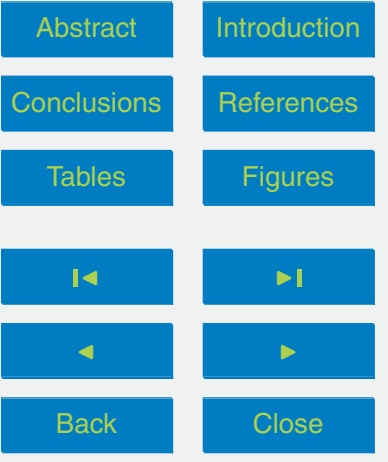

Back

Full Screen / Esc

Printer-friendly Version

Interactive Discussion 
Mahendra Rai, Alka Yadav and Aniket Gade: Silver nanoparticles as a new generation of antimicrobials, Biotechnol. Adv., 27, 76-83, 2005.

Mahesh, B. and Satish, S.: Antimicrobial Activity of Some Important Medicinal Plant against Plant and Human Pathogens, World J. Agr. Sci., 4, 839-843, 2008.

5 Martinez, M. J., Betancourt, J., Alonso Gonzalez, N., and Jauregui, A.: Screening of some Cuban medicinal plants for antimicrobial activity, J. Ethnopharmacol., 52, 171-174, 1996.

Mondal, S., Mahapatra, S. C., Mirdha, B. R., and Naik, S. N.: Antimicrobial activities of essential oils obtained from fresh and dried leaves of Ocimum sanctum (L.) against enteric bacteria and yeast, Acta Horticulturae (ISHS), 756, 267-270, 2007.

10 Nostro, A., Germano, M. P., Angelo, V. D., Marino, A., and Cannatelli, M. A.: Extraction methods and bioautography for evaluation of medicinal plant antimicrobial activity, Lett. Appl. Microbiol., 30, 379-384, 2000.

Pavithra Sundaramurthi, Saranya Dhandapani, and Shankar Bharathi Ponnusamy: Effect of Tulsi (Ocimum Sanctum) as a Disinfectant for Water Treatment, Hitek Journal of Biological

15 Science \& Bioengineering, 1, 1-7, 2012.

Pooja Agarwal, Nagesh, L., and Murlikrishnan: Evaluation of the antimicrobial activity of various concentrations of Tulsi (Ocimum sanctum) extract against Streptococcus mutans: An in vitro study, Indian Journal of Dental Research, 21, 357-359, 2010.

Rios, J. L. and Recio, M. C.: Medicinal plants and antimicrobial activity, J. Ethnopharmacol., 100, 80-84, 2005.

Shiv Shankar, S., Akhilesh Rai, Absar Ahmad, and Murali Sastry: Rapid synthesis of Au, Ag, and bimetallic Au core-Ag shellparticles using Neem (Azadirachta indica) leaf broth, Journal of Colloid and Interface Science, 275, 496-502, 2004.

Siavash Iravani: Green synthesis of metal nanoparticles using plants, Green Chemistry, 13, 2638-2650, 2011.

Srinivasan, D., Sangeetha Nathan, Suresh, T., and Lakshmana Perumalsamy, P.: Antimicrobial activity of certain Indian medicinal plants used in folkloric medicine, J. Ethnopharmacol., 74, 217-220, 2001.

Sunil Somani, B., Nitin ingole, W., and Shrikant Patil, S.: Performance evaluation of natural herbs for antibacterial activity in water purification, Int. J. Eng. Sci. Technol., 3, 7170-7174, 2011.

Venugopal Amrita, Dasani Sonal and Rai Shalini: Antibacterial Effect of Herbs and Spices Extract on Escherichia coli, Electronic Journal of Biology, 5, 40-44, 2009.

\section{Antibacterial activity \\ of selected natural herbs \\ P. S. Harikumar and \\ C. M. Manjusha}

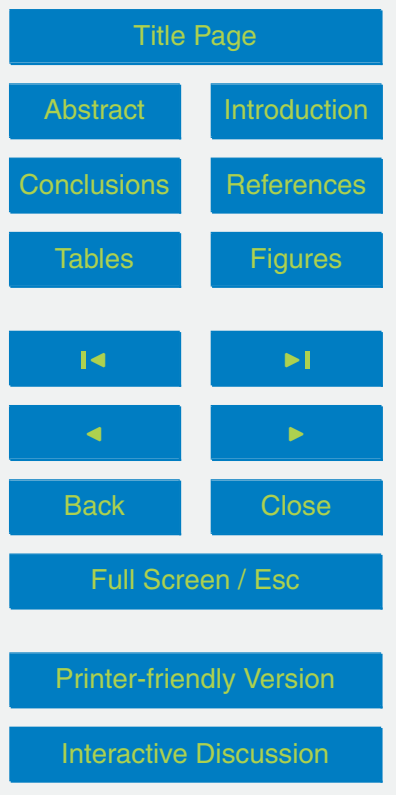


Table 1. Mean, median and standard deviation of percentage reduction values of total coliforms with respect to different herbs.

\begin{tabular}{|c|c|c|c|c|c|c|c|}
\hline Site no. & Herbal extracts & Concentration $(\mathrm{mL})$ & TC 1 & TC 2 & Mean & Median & TC value \\
\hline \multirow[t]{6}{*}{1} & Ocimum sanctum & 2.5 & 55.1 & 55.3 & 55.2 & 55.2 & $55.2 \pm 0.14$ \\
\hline & & 5 & 63.3 & 63.5 & 63.4 & 63.4 & $63.4 \pm 0.14$ \\
\hline & & 7.5 & 70 & 70.2 & 70.1 & 70.1 & $70.1 \pm 0.14$ \\
\hline & & 10 & 85.3 & 85.3 & 85.3 & 85.3 & $85.3 \pm 0$ \\
\hline & & 12.5 & 87.3 & 87.5 & 87.4 & 87.4 & $87.4 \pm 0.14$ \\
\hline & & 15 & 89.2 & 89.4 & 89.3 & 89.3 & $89.3 \pm 0.14$ \\
\hline \multirow[t]{6}{*}{2} & Ocimum kilimandscharicum & 2.5 & 44.2 & 44.4 & 44.3 & 44.3 & $44.3 \pm 0.14$ \\
\hline & & 5 & 59.1 & 59.3 & 59.2 & 59.2 & $59.2 \pm 0.14$ \\
\hline & & 7.5 & 64.7 & 64.9 & 64.8 & 64.8 & $64.8 \pm 0.14$ \\
\hline & & 10 & 71.1 & 71.3 & 71.2 & 71.2 & $71.2 \pm 0.14$ \\
\hline & & 12.5 & 75 & 75.2 & 75.1 & 75.1 & $75.1 \pm 0.14$ \\
\hline & & 15 & 85.3 & 85.5 & 85.4 & 85.4 & $85.4 \pm 0.14$ \\
\hline \multirow[t]{6}{*}{3} & Ocimum tenuiflorum & 2.5 & 40.9 & 40.9 & 40.9 & 40.9 & $40.9 \pm 0$ \\
\hline & & 5 & 53.1 & 53.3 & 53.2 & 53.2 & $53.2 \pm 0.14$ \\
\hline & & 7.5 & 60.2 & 60.4 & 60.3 & 60.3 & $60.3 \pm 0.14$ \\
\hline & & 10 & 70 & 70 & 70 & 70 & $70 \pm 0$ \\
\hline & & 12.5 & 72.3 & 72.5 & 72.4 & 72.4 & $72.4 \pm 0.14$ \\
\hline & & 15 & 78.7 & 78.9 & 78.8 & 78.8 & $78.8 \pm 0.14$ \\
\hline \multirow[t]{6}{*}{4} & Azadirachta indica & 2.5 & 34.1 & 34.3 & 34.2 & 34.2 & $34.2 \pm 0.14$ \\
\hline & & 5 & 47.2 & 47.4 & 47.3 & 47.3 & $47.3 \pm 0.14$ \\
\hline & & 7.5 & 50 & 50 & 50 & 50 & $50 \pm 0$ \\
\hline & & 10 & 59.7 & 59.9 & 59.8 & 59.8 & $59.8 \pm 0.14$ \\
\hline & & 12.5 & 60 & 60.2 & 60.1 & 60.1 & $60.1 \pm 0.14$ \\
\hline & & 15 & 62.1 & 62.3 & 62.2 & 62.2 & $62.2 \pm 0.14$ \\
\hline \multirow[t]{6}{*}{5} & Simarouba glauca & 2.5 & 26.1 & 26.3 & 26.2 & 26.2 & $26.2 \pm 0.14$ \\
\hline & & 5 & 38.7 & 38.9 & 38.8 & 38.8 & $38.8 \pm 0.14$ \\
\hline & & 7.5 & 43.1 & 43.3 & 43.2 & 43.2 & $43.2 \pm 0.14$ \\
\hline & & 10 & 48 & 48.2 & 48.1 & 48.1 & $48.1 \pm 0.14$ \\
\hline & & 12.5 & 49.1 & 49.3 & 49.2 & 49.2 & $49.2 \pm 0.14$ \\
\hline & & 15 & 50.2 & 50.4 & 50.3 & 50.3 & $50.3 \pm 0.14$ \\
\hline
\end{tabular}

DWESD

6, 199-231, 2013

Antibacterial activity of selected natural herbs

P. S. Harikumar and

C. M. Manjusha

\section{Title Page}

Abstract

Introduction

Conclusions

References

Tables

Figures

14

4

Back

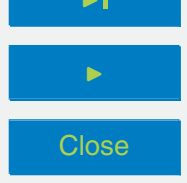

Full Screen / Esc

Printer-friendly Version

Interactive Discussion 
Table 1. Continued.

\begin{tabular}{|c|c|c|c|c|c|c|c|}
\hline Site no. & Herbal extracts & Concentration $(\mathrm{mL})$ & TC 1 & TC 2 & Mean & Median & $\mathrm{TC}$ value \\
\hline \multirow[t]{6}{*}{6} & Caesalpinia sappan & 2.5 & 36 & 36 & 36 & 36 & $36 \pm 0$ \\
\hline & & 5 & 48.3 & 48.5 & 48.4 & 48.4 & $48.4 \pm 0.14$ \\
\hline & & 7.5 & 52.1 & 52.3 & 52.2 & 52.2 & $52.2 \pm 0.14$ \\
\hline & & 10 & 60.2 & 60.4 & 60.3 & 60.3 & $60.3 \pm 0.14$ \\
\hline & & 12.5 & 64.1 & 64.3 & 64.2 & 64.2 & $64.2 \pm 0.14$ \\
\hline & & 15 & 68.7 & 68.9 & 68.8 & 68.8 & $68.8 \pm 0.14$ \\
\hline \multirow[t]{6}{*}{7} & Cuminum cyminum & 2.5 & 13.8 & 14 & 13.9 & 13.9 & $13.9 \pm 0.14$ \\
\hline & & 5 & 14.3 & 14.5 & 14.4 & 14.4 & $14.4 \pm 0.14$ \\
\hline & & 7.5 & 15 & 15 & 15 & 15 & $15 \pm 0$ \\
\hline & & 10 & 15.8 & 16 & 15.9 & 15.9 & $15.9 \pm 0.14$ \\
\hline & & 12.5 & 16.9 & 17.1 & 17 & 17 & $17 \pm 0.14$ \\
\hline & & 15 & 18.1 & 18.3 & 18.2 & 18.2 & $18.2 \pm 0.14$ \\
\hline \multirow[t]{6}{*}{8} & Vetiveria zizanioides & 2.5 & 39.8 & 40 & 39.9 & 39.9 & $39.9 \pm 0.14$ \\
\hline & & 5 & 49 & 49.2 & 49.1 & 49.1 & $49.1 \pm 0.14$ \\
\hline & & 7.5 & 58.1 & 58.3 & 58.2 & 58.2 & $58.2 \pm 0.14$ \\
\hline & & 10 & 67.7 & 67.7 & 67.7 & 67.7 & $67.7 \pm 0$ \\
\hline & & 12.5 & 68 & 68.2 & 68.1 & 68.1 & $68.1 \pm 0.14$ \\
\hline & & 15 & 78.3 & 78.3 & 78.3 & 78.3 & $78.3 \pm 0$ \\
\hline \multirow[t]{6}{*}{9} & Saraca indica & 2.5 & 30 & 30.2 & 30.1 & 30.1 & $30.1 \pm 0.14$ \\
\hline & & 5 & 43 & 43.2 & 43.1 & 43.1 & $43.1 \pm 0.14$ \\
\hline & & 7.5 & 45.3 & 45.3 & 45.3 & 45.3 & $45.3 \pm 0$ \\
\hline & & 10 & 55.9 & 56.1 & 55 & 55 & $55 \pm 0.14$ \\
\hline & & 12.5 & 56 & 56.2 & 56.1 & 56.1 & $56.1 \pm 0.14$ \\
\hline & & 15 & 56.5 & 56.7 & 56.6 & 56.6 & $56.6 \pm 0.14$ \\
\hline \multirow[t]{6}{*}{10} & Murraya koenigii & 2.5 & 32.2 & 32.2 & 32.2 & 32.2 & $32.2 \pm 0$ \\
\hline & & 5 & 45.1 & 45.3 & 45.2 & 45.2 & $45.2 \pm 0.14$ \\
\hline & & 7.5 & 46.5 & 46.7 & 46.6 & 46.6 & $46.6 \pm 0.14$ \\
\hline & & 10 & 57.4 & 57.6 & 57.5 & 57.5 & $57.5 \pm 0.14$ \\
\hline & & 12.5 & 57.9 & 58.1 & 58 & 58 & $58 \pm 0.14$ \\
\hline & & 15 & 58.2 & 58.2 & 58.2 & 58.2 & $58.2 \pm 0$ \\
\hline
\end{tabular}

Note: TC - total coliforms
DWESD

6, 199-231, 2013

Antibacterial activity of selected natural herbs

\section{P. S. Harikumar and \\ C. M. Manjusha}

\section{Title Page}

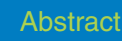

Introduction

Conclusions

References

Tables

Figures

14

$>1$

4

Back

Close

Full Screen / Esc

Printer-friendly Version

Interactive Discussion 
Table 2. Mean, median and standard deviation of percentage reduction values of faecal coliforms with respect to different herbs.

\begin{tabular}{|c|c|c|c|c|c|c|c|}
\hline Site no. & Herbal extracts & Concentration $(\mathrm{mL})$ & FC 1 & FC 2 & Mean & Median & FC value \\
\hline \multirow[t]{6}{*}{1} & Ocimum sanctum & 2.5 & 55.7 & 55.7 & 55.7 & 55.7 & $55.7 \pm 0$ \\
\hline & & 5 & 64.1 & 64.3 & 64.2 & 64.2 & $64.2 \pm 0.14$ \\
\hline & & 7.5 & 70.8 & 70.8 & 70.8 & 70.8 & $70.8 \pm 0$ \\
\hline & & 10 & 86.1 & 86.3 & 86.2 & 86.2 & $86.2 \pm 0.14$ \\
\hline & & 12.5 & 90.4 & 90.6 & 90.5 & 90.5 & $90.5 \pm 0.14$ \\
\hline & & 15 & 92.2 & 92.4 & 92.3 & 92.3 & $92.3 \pm 0.14$ \\
\hline \multirow[t]{6}{*}{2} & Ocimum kilimandscharicum & 2.5 & 45.2 & 45.4 & 45.3 & 45.3 & $45.3 \pm 0.14$ \\
\hline & & 5 & 60 & 60 & 60 & 60 & $60 \pm 0$ \\
\hline & & 7.5 & 65.2 & 65.4 & 65.3 & 65.3 & $65.3 \pm 0.14$ \\
\hline & & 10 & 72.3 & 72.5 & 72.4 & 72.4 & $72.4 \pm 0.14$ \\
\hline & & 12.5 & 82.8 & 83 & 82.9 & 82.9 & $82.9 \pm 0.14$ \\
\hline & & 15 & 87.9 & 88.1 & 88 & 88 & $88 \pm 0.14$ \\
\hline \multirow[t]{6}{*}{3} & Ocimum tenuiflorum & 2.5 & 44.2 & 44.4 & 44.3 & 44.3 & $44.3 \pm 0.14$ \\
\hline & & 5 & 54.6 & 54.8 & 54.7 & 54.7 & $54.7 \pm 0.14$ \\
\hline & & 7.5 & 63.1 & 63.3 & 63.2 & 63.2 & $63.2 \pm 0.14$ \\
\hline & & 10 & 70.4 & 70.6 & 70.5 & 70.5 & $70.5 \pm 0.14$ \\
\hline & & 12.5 & 78.7 & 78.9 & 78.8 & 78.8 & $78.8 \pm 0.14$ \\
\hline & & 15 & 79.1 & 79.3 & 79.2 & 79.2 & $79.2 \pm 0.14$ \\
\hline \multirow[t]{6}{*}{4} & Azadirachta indica & 2.5 & 37.2 & 37.2 & 37.2 & 37.2 & $37.2 \pm 0$ \\
\hline & & 5 & 48.5 & 48.7 & 48.6 & 48.6 & $48.6 \pm 0.14$ \\
\hline & & 7.5 & 50.2 & 50.4 & 50.3 & 50.3 & $50.3 \pm 0.14$ \\
\hline & & 10 & 62.1 & 62.3 & 62.2 & 62.2 & $62.2 \pm 0.14$ \\
\hline & & 12.5 & 63 & 63.2 & 63.1 & 63.1 & $63.1 \pm 0.14$ \\
\hline & & 15 & 69.1 & 69.3 & 69.2 & 69.2 & $69.2 \pm 0.14$ \\
\hline \multirow[t]{6}{*}{5} & Simarouba glauca & 2.5 & 29.1 & 29.3 & 29.2 & 29.2 & $29.2 \pm 0.14$ \\
\hline & & 5 & 40 & 40.2 & 40.1 & 40.1 & $40.1 \pm 0.14$ \\
\hline & & 7.5 & 46 & 46.2 & 46.1 & 46.1 & $46.1 \pm 0.14$ \\
\hline & & 10 & 55.2 & 55.4 & 55.3 & 55.3 & $55.3 \pm 0.14$ \\
\hline & & 12.5 & 64.1 & 64.3 & 64.2 & 64.2 & $64.2 \pm 0.14$ \\
\hline & & 15 & 65.1 & 65.3 & 65.2 & 65.2 & $65.2 \pm 0.14$ \\
\hline
\end{tabular}

DWESD

6, 199-231, 2013

Antibacterial activity of selected natural herbs

P. S. Harikumar and

C. M. Manjusha

\section{Title Page}

Abstract

Introduction

Conclusions

References

Tables

Figures

14

4

Back

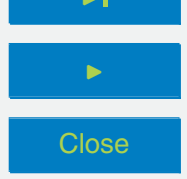

Full Screen / Esc

Printer-friendly Version

Interactive Discussion 
Table 2. Continued.

\begin{tabular}{|c|c|c|c|c|c|c|c|}
\hline Site no. & Herbal extracts & Concentration $(\mathrm{mL})$ & $\mathrm{FC} 1$ & FC 2 & Mean & Median & FC value \\
\hline \multirow[t]{6}{*}{6} & Caesalpinia sappan & 2.5 & 38.3 & 38.5 & 38.4 & 38.4 & $38.4 \pm 0.14$ \\
\hline & & 5 & 49.5 & 49.7 & 49.6 & 49.6 & $49.6 \pm 0.14$ \\
\hline & & 7.5 & 56.1 & 56.3 & 56.2 & 56.2 & $56.2 \pm 0.14$ \\
\hline & & 10 & 68 & 68 & 68 & 68 & $68 \pm 0$ \\
\hline & & 12.5 & 70.1 & 70.3 & 70.2 & 70.2 & $70.2 \pm 0.14$ \\
\hline & & 15 & 74.1 & 74.3 & 74.2 & 74.2 & $74.2 \pm 0.14$ \\
\hline \multirow[t]{6}{*}{7} & Cuminum cyminum & 2.5 & 14.1 & 14.3 & 14.2 & 14.2 & $14.2 \pm 0.14$ \\
\hline & & 5 & 14.4 & 14.6 & 14.5 & 14.5 & $14.5 \pm 0.14$ \\
\hline & & 7.5 & 15.1 & 15.3 & 15.2 & 15.2 & $15.2 \pm 0.14$ \\
\hline & & 10 & 16.2 & 16.4 & 16.3 & 16.3 & $16.3 \pm 0.14$ \\
\hline & & 12.5 & 18.3 & 18.5 & 18.4 & 18.4 & $18.4 \pm 0.14$ \\
\hline & & 15 & 20.4 & 20.6 & 20.5 & 20.5 & $20.5 \pm 0.14$ \\
\hline \multirow[t]{6}{*}{8} & Vetiveria zizanioides & 2.5 & 42.9 & 43.1 & 43 & 43 & $43 \pm 0.14$ \\
\hline & & 5 & 50.3 & 50.3 & 50.3 & 50.3 & $50.3 \pm 0$ \\
\hline & & 7.5 & 60.3 & 60.5 & 60.4 & 60.4 & $60.4 \pm 0.14$ \\
\hline & & 10 & 68.1 & 68.3 & 68.2 & 68.2 & $68.2 \pm 0.14$ \\
\hline & & 12.5 & 72.2 & 72.4 & 72.3 & 72.3 & $72.3 \pm 0.14$ \\
\hline & & 15 & 80 & 80.2 & 80.1 & 80.1 & $80.1 \pm 0.14$ \\
\hline \multirow[t]{6}{*}{9} & Saraca indica & 2.5 & 32.7 & 32.9 & 32.8 & 32.8 & $32.8 \pm 0.14$ \\
\hline & & 5 & 44.2 & 44.2 & 44.2 & 44.2 & $44.2 \pm 0$ \\
\hline & & 7.5 & 47.2 & 47.4 & 47.3 & 47.3 & $47.3 \pm 0.14$ \\
\hline & & 10 & 52.2 & 52.4 & 52.3 & 52.3 & $52.3 \pm 0.14$ \\
\hline & & 12.5 & 65.7 & 65.9 & 65.8 & 65.8 & $65.8 \pm 0.14$ \\
\hline & & 15 & 69.1 & 69.1 & 69.1 & 69.1 & $69.1 \pm 0$ \\
\hline \multirow[t]{6}{*}{10} & Murraya koenigii & 2.5 & 33 & 33.2 & 33.1 & 33.1 & $33.1 \pm 0.14$ \\
\hline & & 5 & 46.3 & 46.3 & 46.3 & 46.3 & $46.3 \pm 0$ \\
\hline & & 7.5 & 49.1 & 49.3 & 49.2 & 49.2 & $49.2 \pm 0.14$ \\
\hline & & 10 & 60.2 & 60.4 & 60.3 & 60.3 & $60.3 \pm 0.14$ \\
\hline & & 12.5 & 60.7 & 60.9 & 60.8 & 60.8 & $60.8 \pm 0.14$ \\
\hline & & 15 & 68.1 & 68.3 & 68.2 & 68.2 & $68.2 \pm 0.14$ \\
\hline
\end{tabular}

Note: FC - faecal coliforms
DWESD

6, 199-231, 2013

Antibacterial activity of selected natural herbs

\section{P. S. Harikumar and \\ C. M. Manjusha}

\section{Title Page}

Abstract

Introduction

Conclusions

References

Tables

Figures

14

$>1$

4

Back

Close

Full Screen / Esc

Printer-friendly Version

Interactive Discussion 
Table 3. Mean, median and standard deviation of percentage reduction values of $E$. coli with respect to different herbs.

\begin{tabular}{|c|c|c|c|c|c|c|c|}
\hline Site no. & Herbal extracts & Concentration $(\mathrm{mL})$ & E. coli1 & E. coli2 & Mean & Median & E. coli value \\
\hline \multirow[t]{6}{*}{1} & Ocimum sanctum & 2.5 & 56 & 56.2 & 56.1 & 56.1 & $56.1 \pm 0.14$ \\
\hline & & 5 & 65.3 & 65.3 & 65.3 & 65.3 & $65.3 \pm 0$ \\
\hline & & 7.5 & 71.1 & 71.3 & 71.2 & 71.2 & $71.2 \pm 0.14$ \\
\hline & & 10 & 87.9 & 88.1 & 88 & 88 & $88 \pm 0.14$ \\
\hline & & 12.5 & 96.2 & 96.2 & 96.2 & 96.2 & $96.2 \pm 0$ \\
\hline & & 15 & 100 & 100 & 100 & 100 & $100 \pm 0$ \\
\hline \multirow[t]{6}{*}{2} & Ocimum kilimandscharicum & 2.5 & 49.4 & 49.4 & 49.4 & 49.4 & $49.4 \pm 0$ \\
\hline & & 5 & 60.1 & 60.3 & 60.2 & 60.2 & $60.2 \pm 0.14$ \\
\hline & & 7.5 & 70.5 & 70.7 & 70.6 & 70.6 & $70.6 \pm 0.14$ \\
\hline & & 10 & 86 & 86.2 & 86.1 & 86.1 & $86.1 \pm 0.14$ \\
\hline & & 12.5 & 91.9 & 92.1 & 92 & 92 & $92 \pm 0.14$ \\
\hline & & 15 & 93.3 & 93.3 & 93.3 & 93.3 & $93.3 \pm 0$ \\
\hline \multirow[t]{6}{*}{3} & Ocimum tenuiflorum & 2.5 & 45 & 45 & 45 & 45 & $45 \pm 0$ \\
\hline & & 5 & 55.2 & 55.4 & 55.3 & 55.3 & $55.3 \pm 0.14$ \\
\hline & & 7.5 & 64.1 & 64.3 & 64.2 & 64.2 & $64.2 \pm 0.14$ \\
\hline & & 10 & 73.1 & 73.3 & 73.2 & 73.2 & $73.2 \pm 0.14$ \\
\hline & & 12.5 & 81.7 & 81.9 & 81.8 & 81.8 & $81.8 \pm 0.14$ \\
\hline & & 15 & 85 & 85.2 & 85.1 & 85.1 & $85.1 \pm 0.14$ \\
\hline \multirow[t]{6}{*}{4} & Azadirachta indica & 2.5 & 38.7 & 38.9 & 38.8 & 38.8 & $38.8 \pm 0.14$ \\
\hline & & 5 & 49.4 & 49.6 & 49.5 & 49.5 & $49.5 \pm 0.14$ \\
\hline & & 7.5 & 54.2 & 54.4 & 54.3 & 54.3 & $54.3 \pm 0.14$ \\
\hline & & 10 & 63.3 & 63.5 & 63.4 & 63.4 & $63.4 \pm 0.14$ \\
\hline & & 12.5 & 74.2 & 74.4 & 74.3 & 74.3 & $74.3 \pm 0.14$ \\
\hline & & 15 & 75.1 & 75.3 & 75.2 & 75.2 & $75.2 \pm 0.14$ \\
\hline \multirow[t]{6}{*}{5} & Simarouba glauca & 2.5 & 30.8 & 31 & 30.9 & 30.9 & $30.9 \pm 0.14$ \\
\hline & & 5 & 42.7 & 42.9 & 42.8 & 42.8 & $42.8 \pm 0.14$ \\
\hline & & 7.5 & 50 & 50.2 & 50.1 & 50.1 & $50.1 \pm 0.14$ \\
\hline & & 10 & 58.3 & 58.3 & 58.3 & 58.3 & $58.3 \pm 0.14$ \\
\hline & & 12.5 & 68.2 & 68.4 & 68.3 & 68.3 & $68.3 \pm 0.14$ \\
\hline & & 15 & 68.9 & 69.1 & 69 & 69 & $69 \pm 0.14$ \\
\hline
\end{tabular}

DWESD

6, 199-231, 2013

Antibacterial activity of selected natural herbs

P. S. Harikumar and

C. M. Manjusha

\section{Title Page}

Abstract

Introduction

Conclusions

References

Tables

Figures

14

4

Back

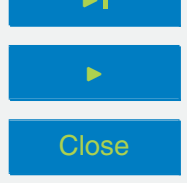

Full Screen / Esc

Printer-friendly Version

Interactive Discussion 
Table 3. Continued.

\begin{tabular}{llrrrrrr}
\hline Site no. & Herbal extracts & Concentration $(\mathrm{mL})$ & E. coli1 & E. coli2 & Mean & Median & E. coli value \\
\hline 6 & Caesalpinia sappan & 2.5 & 40.1 & 40.3 & 40.2 & 40.2 & $40.2 \pm 0.14$ \\
& & 5 & 51.2 & 51.4 & 51.3 & 51.3 & $51.3 \pm 0.14$ \\
& & 5.5 & 57.1 & 57.3 & 57.2 & 57.2 & $57.2 \pm 0.14$ \\
& & 10 & 68.5 & 68.5 & 68.5 & 68.5 & $68.5 \pm 0.14$ \\
& & 12.5 & 76.4 & 76.6 & 76.5 & 76.5 & $76.5 \pm 0.14$ \\
& & 75 & 76.8 & 77 & 76.9 & 76.9 & $76.9 \pm 0.14$ \\
\hline 7 & Cuminum cyminum & 2.5 & 15.2 & 15.4 & 15.3 & 15.3 & $15.3 \pm 0.14$ \\
& & 5 & 16.8 & 16.8 & 16.8 & 16.8 & $16.8 \pm 0$ \\
& & 7.5 & 20.2 & 20.4 & 20.3 & 20.3 & $20.3 \pm 0.14$ \\
& & 10 & 22.3 & 22.5 & 22.4 & 22.4 & $22.4 \pm 0.14$ \\
& & 12.5 & 24.7 & 24.9 & 24.8 & 24.8 & $24.8 \pm 0.14$ \\
& & 15 & 26.2 & 26.2 & 26.2 & 26.2 & $26.2 \pm 0$ \\
\hline 8 & 2.5 & 43.2 & 43.4 & 43.3 & 43.3 & $43.3 \pm 0.14$ \\
& Vetiveria zizanioides & 5 & 53.1 & 53.1 & 53.1 & 53.1 & $53.1 \pm 0$ \\
& & 7.5 & 60.5 & 60.7 & 60.6 & 60.6 & $60.6 \pm 0.14$ \\
& 10 & 70 & 70.2 & 70.1 & 70.1 & $70.1 \pm 0.14$ \\
& & 12.5 & 77.7 & 77.7 & 77.7 & 77.7 & $77.7 \pm 0$ \\
& & 15 & 80.2 & 80.4 & 80.3 & 80.3 & $80.3 \pm 0.14$ \\
\hline 9 & 2.5 & 33.3 & 33.5 & 33.4 & 33.4 & $33.4 \pm 0.14$ \\
& & 5 & 45.5 & 45.7 & 45.6 & 45.6 & $45.6 \pm 0.14$ \\
& & 5.5 & 51 & 51 & 51 & 51 & $51 \pm 0$ \\
& & 10 & 60.1 & 60.3 & 60.2 & 60.2 & $60.2 \pm 0.14$ \\
& & 12.5 & 71.8 & 72 & 71.9 & 71.9 & $71.9 \pm 0.14$ \\
& & 15 & 72.3 & 72.5 & 72.4 & 72.4 & $72.4 \pm 0.14$ \\
\hline \multirow{2}{*}{ Saraca indica } & 2.5 & 34.1 & 34.3 & 34.2 & 34.2 & $34.2 \pm 0.14$ \\
& & 5 & 47.3 & 47.3 & 47.3 & 47.3 & $47.3 \pm 0$ \\
& & 10 & 52.1 & 52.3 & 52.2 & 52.2 & $52.2 \pm 0.14$ \\
& & 62.6 & 62.8 & 62.7 & 62.7 & $62.7 \pm 0.14$ \\
& & 73.7 & 73.9 & 73.8 & 73.8 & $73.8 \pm 0.14$ \\
& & 74.1 & 74.1 & 74.1 & $74.1 \pm 0$ \\
\hline & & & & & &
\end{tabular}

DWESD

6, 199-231, 2013

Antibacterial activity of selected natural herbs

\section{P. S. Harikumar and \\ C. M. Manjusha}

\section{Title Page}

Abstract

Introduction

Conclusions

References

Tables

Figures

14

$>1$

4

Back

Close

\section{Full Screen / Esc}

Printer-friendly Version

Interactive Discussion 


\section{DWESD}

Table 4. Details of sampling stations.

6, 199-231, 2013

\begin{tabular}{llll}
\hline Site no. & Sample code & Sampling station & Panchayath/Municipality/Corporation \\
\hline 1 & T1 & Eranjikkal & Kozhikode Corporation \\
2 & T2 & Vengeri & Kozhikode Corporation \\
3 & T3 & Cherinchal Staff Quarters & Kunnamangalam \\
4 & T4 & Chettikulam & Kozhikode Corporation \\
5 & T5 & Panthalayani & Koyilandy \\
6 & T6 & Villoonniyal & Thenjipalam \\
7 & T7 & Near IIM & Kunnamangalam \\
8 & T8 & Aakkoli & Kunnamangalam \\
9 & T9 & Near Markaz school & Kunnamangalam \\
10 & T10 & Manakadavu & Olavanna \\
11 & T11 & Pallipoyil & Chelannur \\
12 & T12 & Viruppil & Peruvayal \\
13 & T13 & Madathil & Peruvayal \\
14 & T14 & Kannamkulangara & Kozhikode Corporation \\
15 & T15 & Ashokapuram & Kozhikode Corporation \\
16 & T16 & Musliyarangadi & Nediyiruppu \\
17 & T17 & Makool Peedika & Vadakara \\
18 & T18 & Bilathikulam & Kozhikode Corporation \\
19 & T19 & Pathammile & Kunnamangalam \\
20 & T20 & Nadakkavu & Kozhikode Corporation \\
21 & T21 & Puliyanthodu & Kunnamangalam \\
22 & T22 & Cherinchal & Kunnamangalam \\
\hline
\end{tabular}

Antibacterial activity of selected natural herbs

P. S. Harikumar and

C. M. Manjusha

\section{Title Page}

\section{Abstract}

Conclusions

Tables

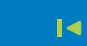

14

\section{Back}

Full Screen / Esc

Printer-friendly Version

Interactive Discussion 
Table 5. Acceptance level of different households.

DWESD

6, 199-231, 2013

\begin{tabular}{llc}
\hline Site no. & Sample code & Acceptance level \\
\hline 1 & T1 & + \\
2 & T2 & + \\
3 & T3 & + \\
4 & T4 & + \\
5 & T5 & + \\
6 & T6 & + \\
7 & T7 & + \\
8 & T8 & + \\
9 & T9 & + \\
10 & T10 & + \\
11 & T11 & + \\
12 & T12 & + \\
13 & T13 & + \\
14 & T14 & - \\
15 & T15 & + \\
16 & T16 & + \\
17 & T17 & + \\
18 & T18 & + \\
19 & T19 & + \\
20 & T20 & + \\
21 & T21 & + \\
22 & T22 & \\
\hline
\end{tabular}

Antibacterial activity of selected natural herbs
P. S. Harikumar and
C. M. Manjusha

Title Page

Abstract

Conclusions

Tables

References
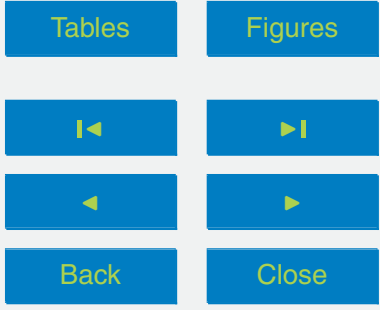

Full Screen / Esc

Printer-friendly Version

Interactive Discussion 


\section{DWESD}

6, 199-231, 2013

\section{Antibacterial activity of selected natural herbs \\ P. S. Harikumar and \\ C. M. Manjusha}

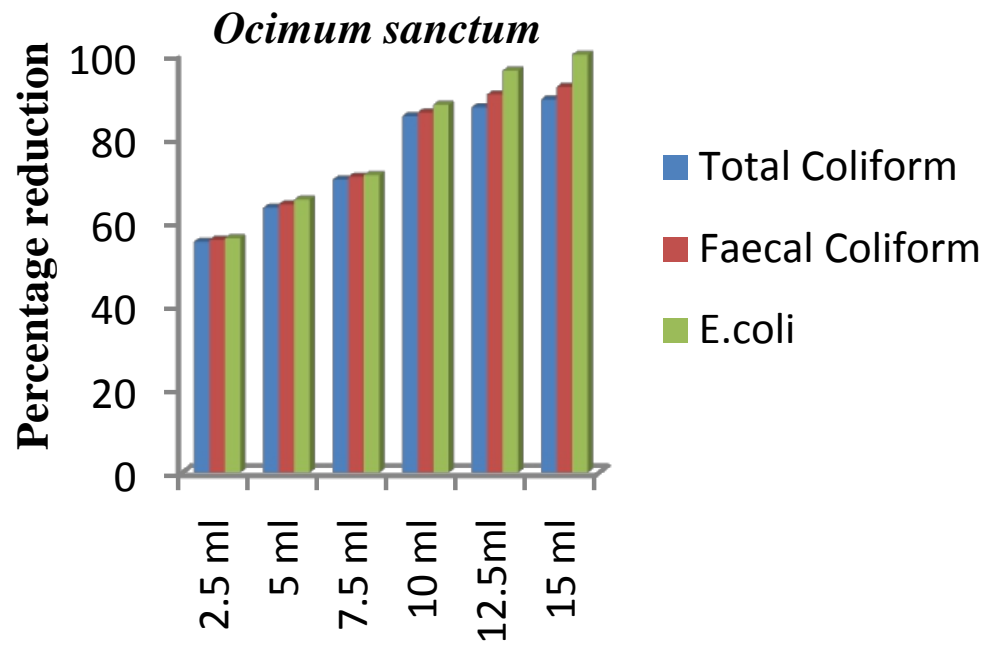

\section{Herbal concentration}

Fig. 1. Effect of $O$. sanctum on the reduction of bacteria.

\section{Back}

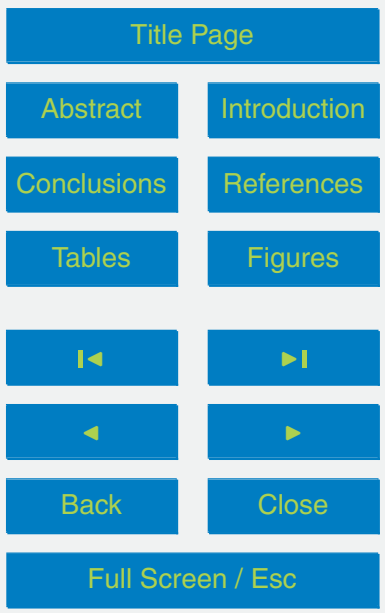

Printer-friendly Version

Interactive Discussion 


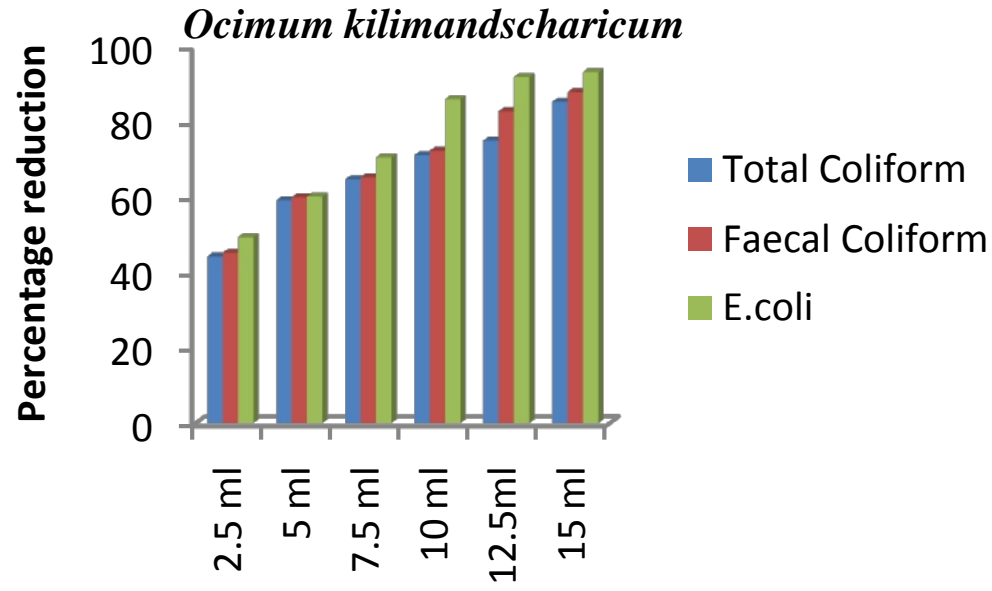

\section{Herbal concentration}

Fig. 2. Effect of $O$. kilimandscharicum on the reduction of bacteria.

DWESD

6, 199-231, 2013

Antibacterial activity of selected natural herbs

\section{P. S. Harikumar and \\ C. M. Manjusha}

\section{Title Page}

Abstract

Conclusions

Tables

References

Figures

14

Back

Full Screen / Esc

Printer-friendly Version

Interactive Discussion 


\section{DWESD}

6, 199-231, 2013

\section{Antibacterial activity of selected natural herbs \\ P. S. Harikumar and \\ C. M. Manjusha}

- Faecal Coliform

E.coli

Title Page

Abstract

Conclusions $\bar{\varepsilon} \bar{\varepsilon} \bar{\varepsilon} \bar{\varepsilon} \bar{\varepsilon}$ ก) ம ก

\section{Herbal concentration}

Fig. 3. Effect of $O$. tenuiflorum on the reduction of bacteria.
Tables References

\section{Figures}

14

4

Back

Full Screen / Esc

Printer-friendly Version

Interactive Discussion 


\section{DWESD}

6, 199-231, 2013

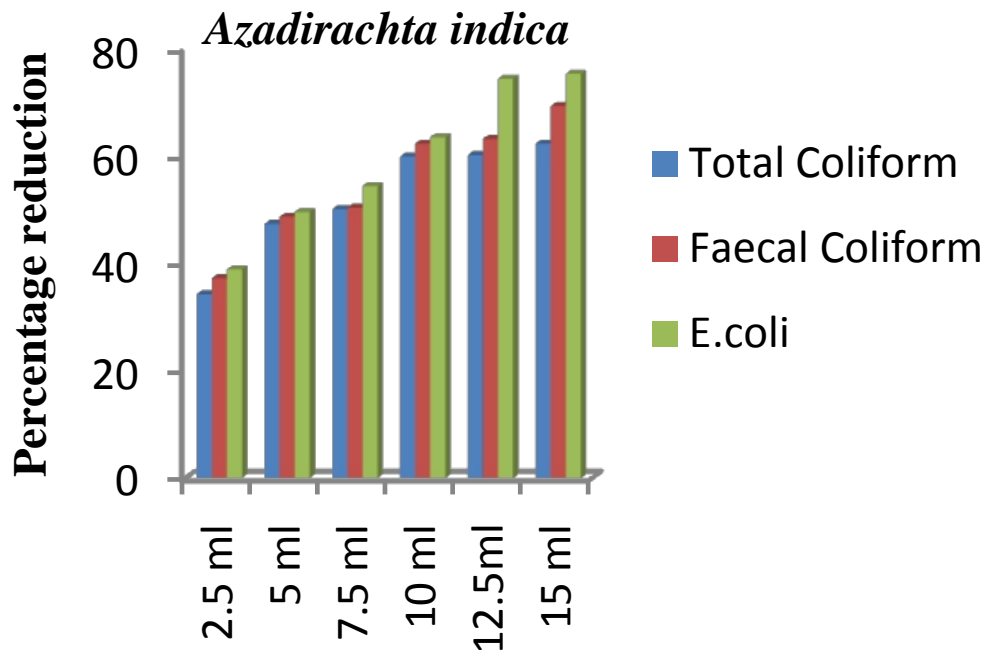

Antibacterial activity of selected natural herbs

P. S. Harikumar and

C. M. Manjusha

\section{Herbal concentration}

Fig. 4. Effect of $A$. indica on the reduction of bacteria.

Title Page

Back

Abstract

Conclusions

Tables

References

Figures

14

4

Full Screen / Esc

Printer-friendly Version

Interactive Discussion 


\section{DWESD}

6, 199-231, 2013

\section{Antibacterial activity of selected natural herbs \\ P. S. Harikumar and \\ C. M. Manjusha}

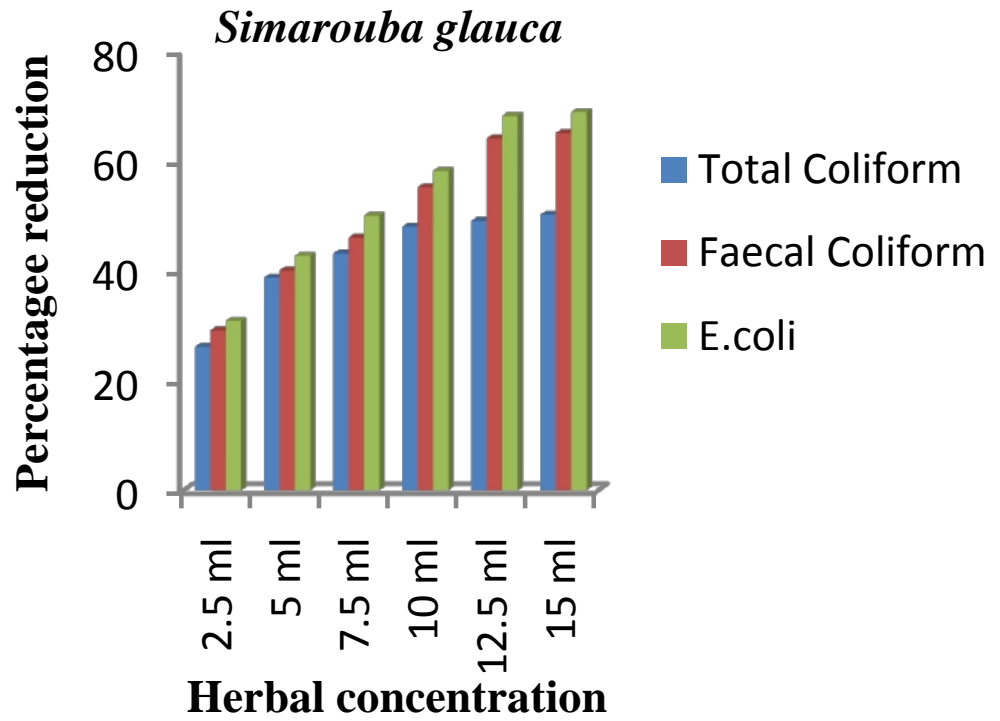

Title Page

Abstract

Conclusions

Tables References

Figures

14

4

Back

Full Screen / Esc

Printer-friendly Version

Interactive Discussion 


\section{DWESD}

6, 199-231, 2013

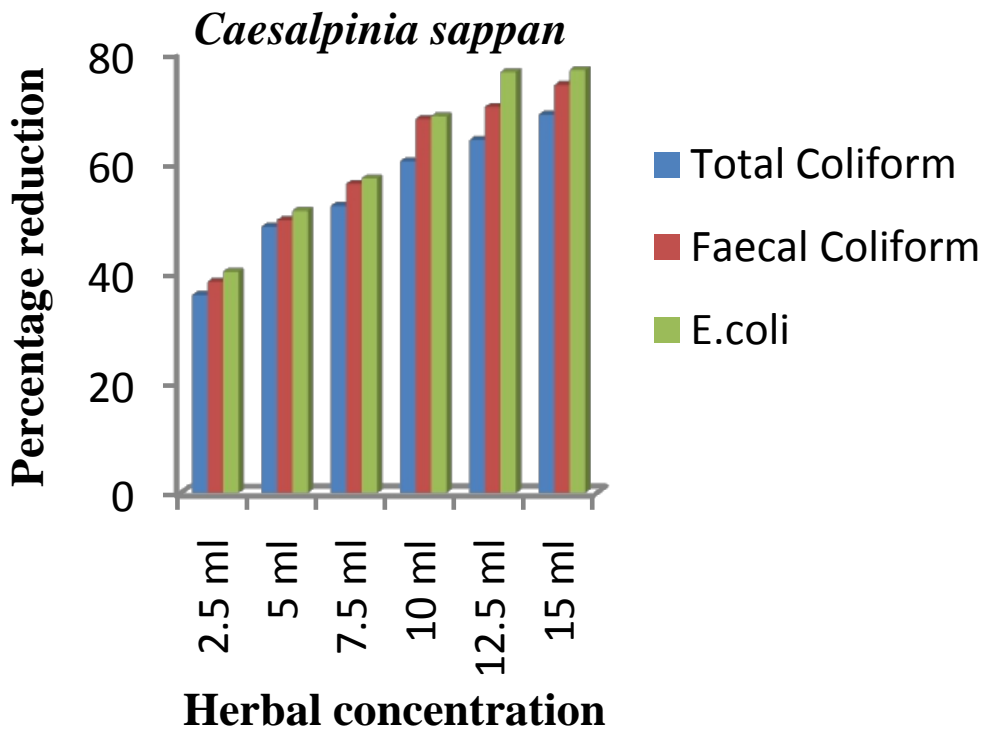

Antibacterial activity of selected natural herbs

P. S. Harikumar and

C. M. Manjusha

Title Page

Abstract

Conclusions

Tables

14

4

Back

Full Screen / Esc

Printer-friendly Version

Interactive Discussion 


\section{DWESD}

6, 199-231, 2013

\section{Antibacterial activity of selected natural herbs \\ P. S. Harikumar and \\ C. M. Manjusha}

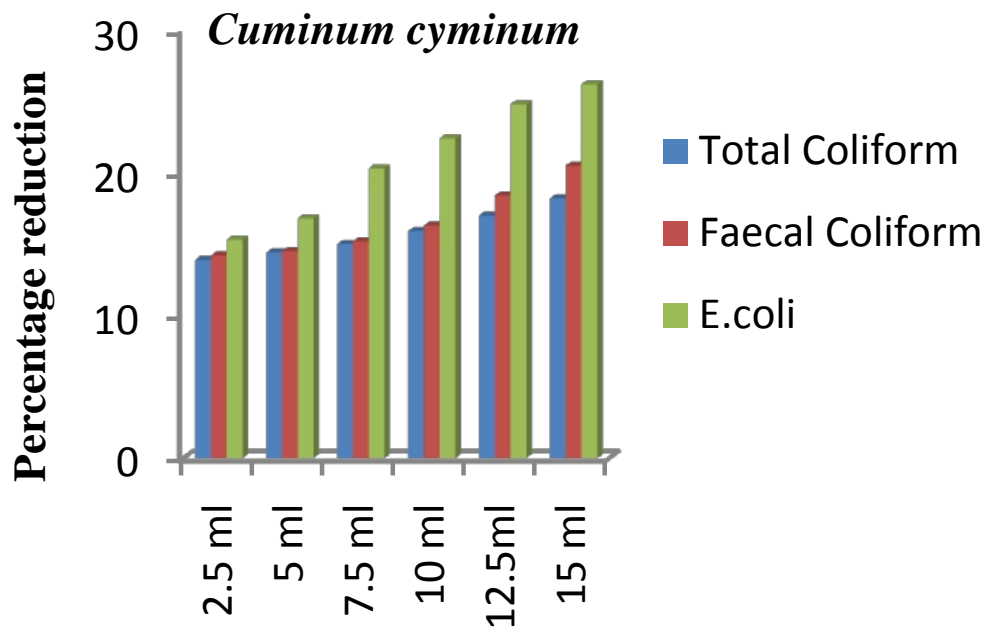

\section{Herbal concentration}

Fig. 7. Effect of C. cyminum on the reduction of bacteria.

\section{Back}

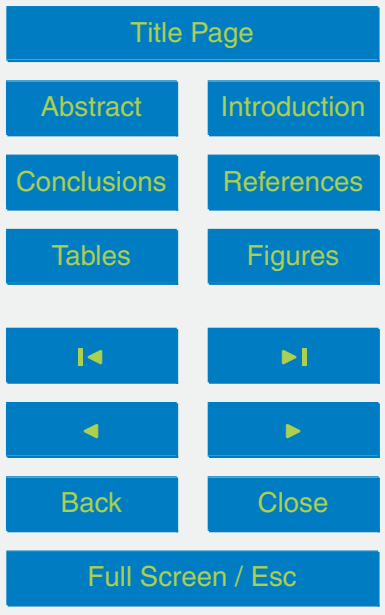

Printer-friendly Version

Interactive Discussion 


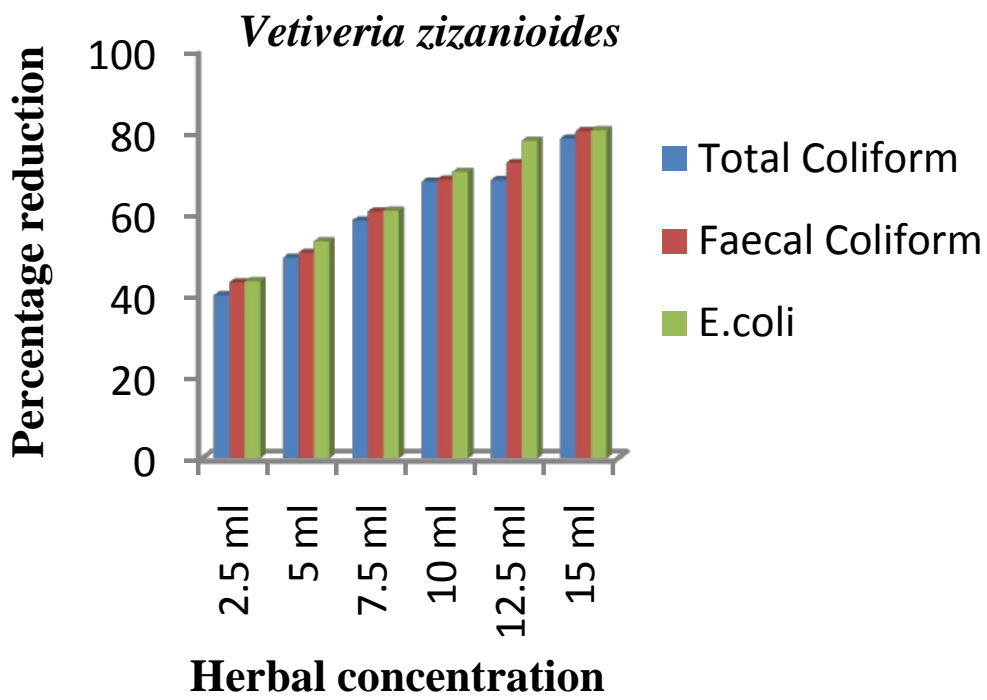

Fig. 8. Effect of $V$. zizanioides on the reduction of bacteria.

\section{DWESD}

6, 199-231, 2013

\section{Antibacterial activity of selected natural herbs \\ P. S. Harikumar and \\ C. M. Manjusha}

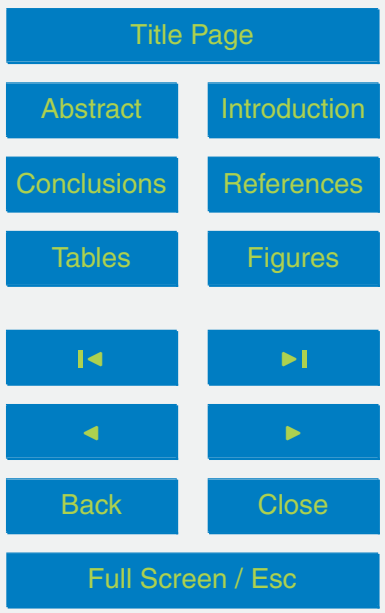

Printer-friendly Version

Interactive Discussion 


\section{DWESD}

6, 199-231, 2013

Antibacterial activity of selected natural herbs

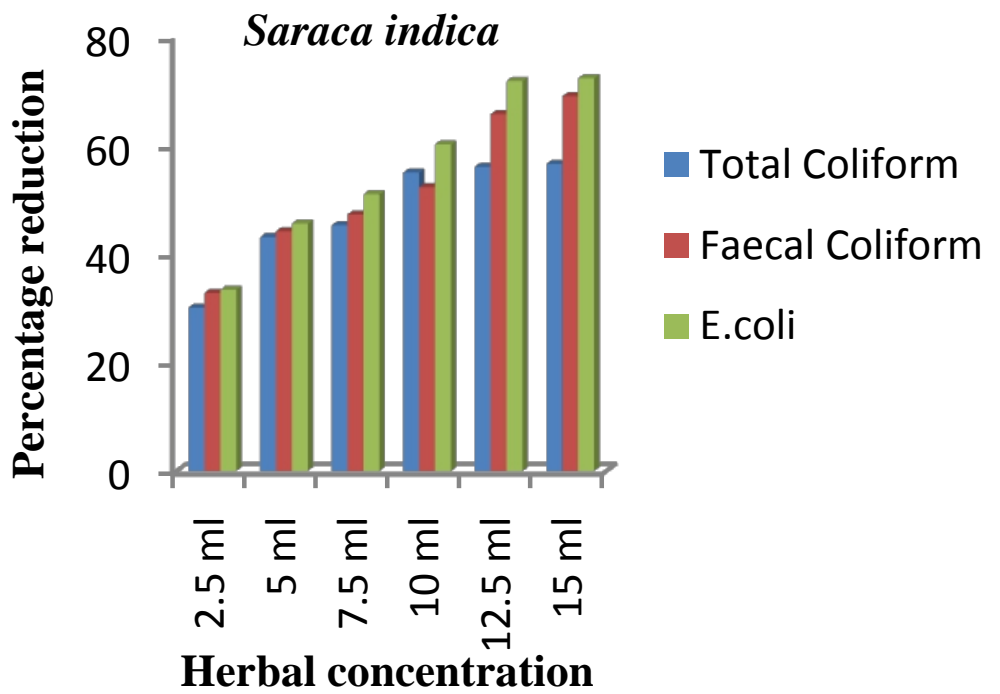

P. S. Harikumar and

C. M. Manjusha

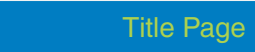

Abstract Introduction

Conclusions References

Tables Figures

14 $>1$ 4 


\section{DWESD}

6, 199-231, 2013

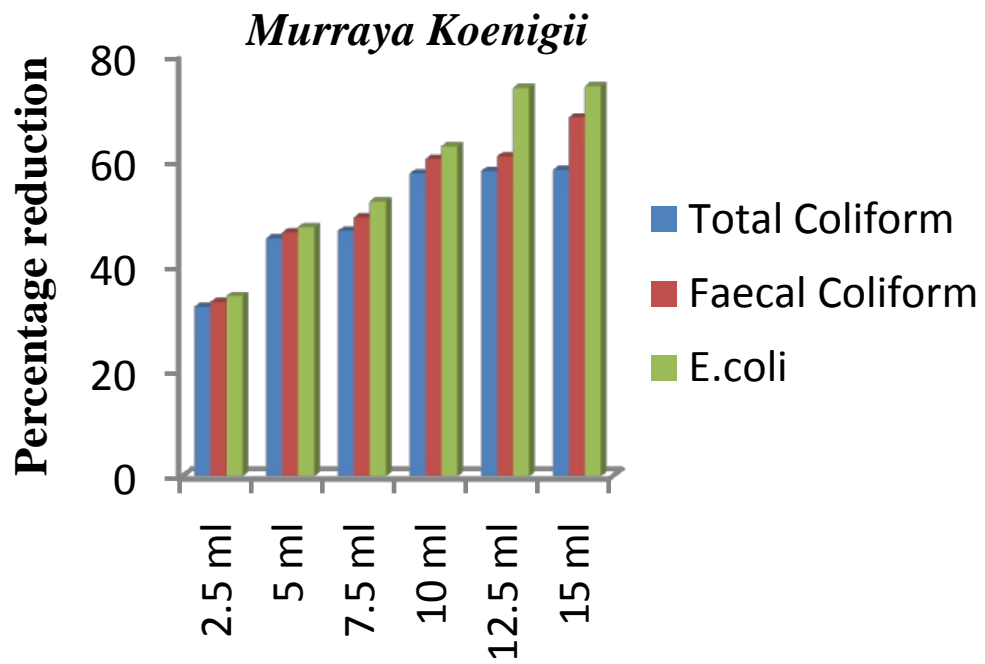

\section{Herbal concentration}

Fig. 10. Effect of $M$. koenigii on the reduction of bacteria.

\section{Antibacterial activity of selected natural herbs \\ P. S. Harikumar and \\ C. M. Manjusha}

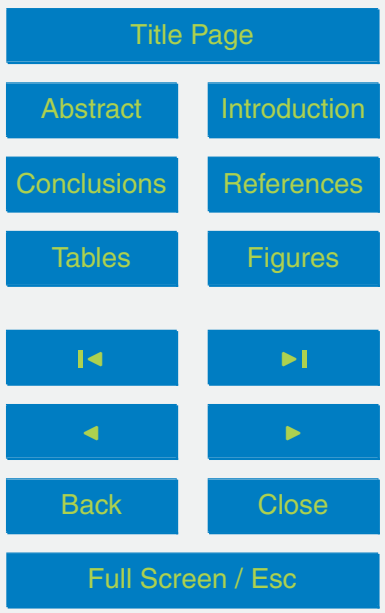

Printer-friendly Version

Interactive Discussion 


\section{DWESD}

6, 199-231, 2013

Antibacterial activity of selected natural herbs

\section{P. S. Harikumar and \\ C. M. Manjusha}

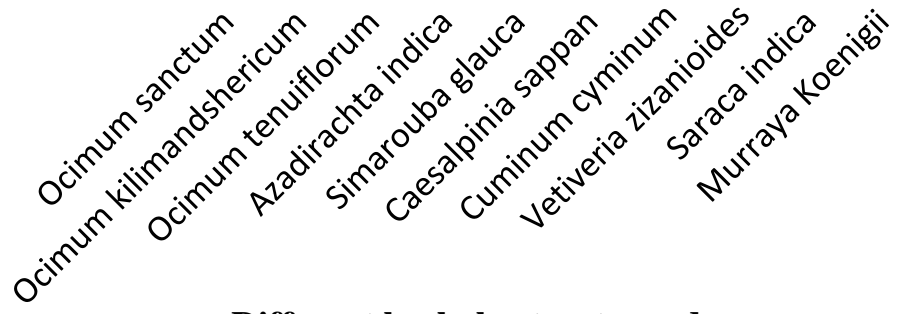

\section{Different herbal extracts used}

Fig. 11. Zone of Inhibition (cm) produced by different herbal extracts.

Title Page

\section{Back}

Abstract

Conclusions

Tables

14

\section{Full Screen / Esc}

Printer-friendly Version

Interactive Discussion 


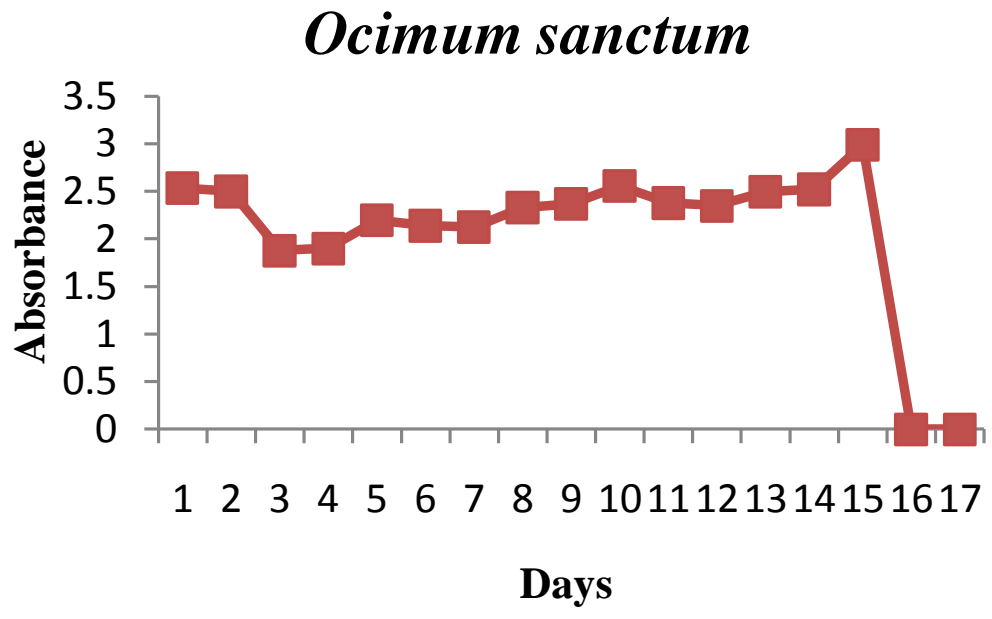

Fig. 12. Stability of $O$. sanctum at $650 \mathrm{~nm}$ during different days of observation.

DWESD

6, 199-231, 2013

Antibacterial activity of selected natural herbs

\section{P. S. Harikumar and \\ C. M. Manjusha}

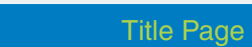

Abstract

Introduction

Conclusions

References

Tables

Figures

14

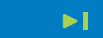

Back

Full Screen / Esc

Printer-friendly Version

Interactive Discussion 


\section{DWESD}

6, 199-231, 2013

\section{Antibacterial activity of selected natural herbs \\ P. S. Harikumar and \\ C. M. Manjusha}
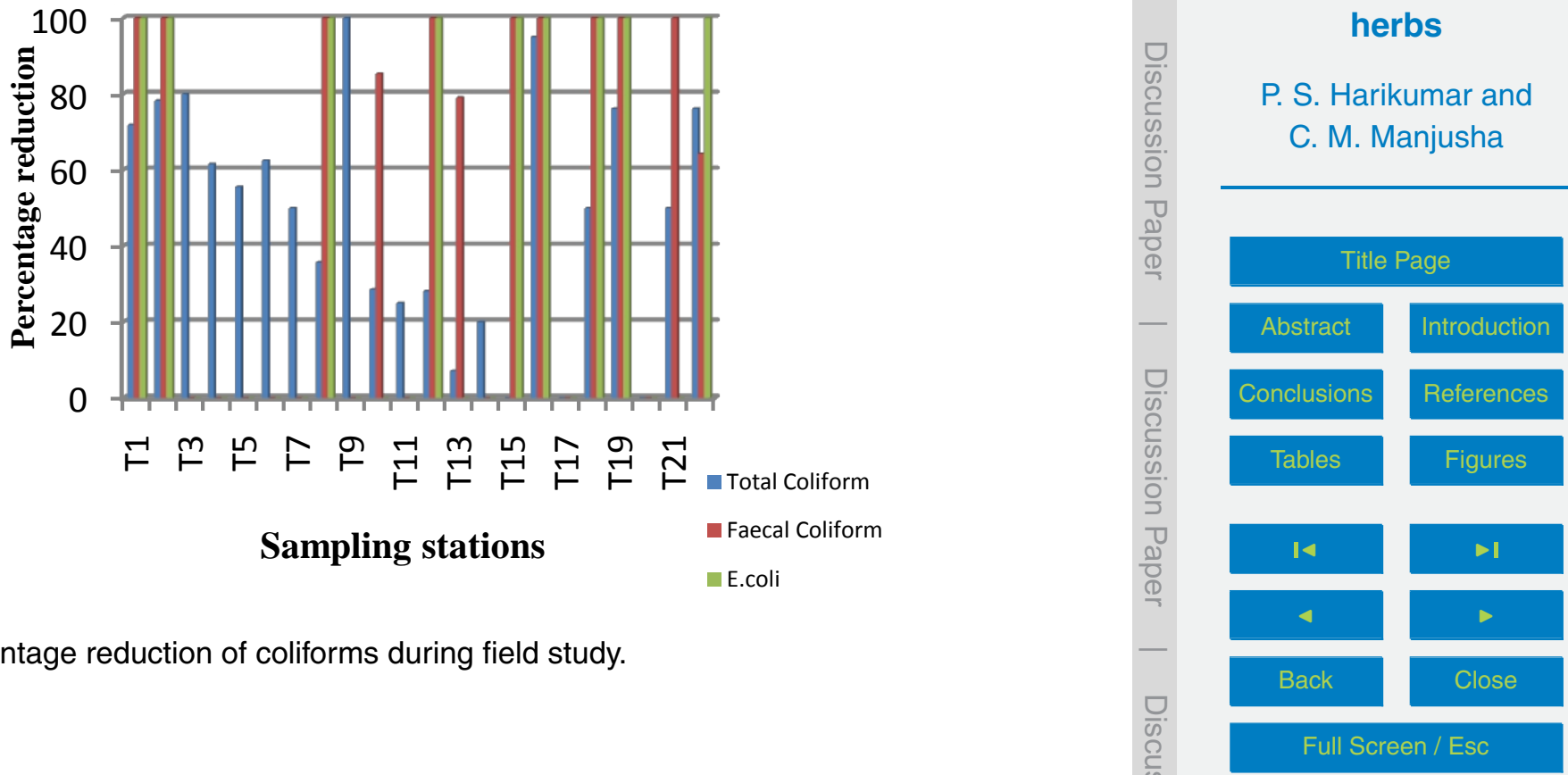

Printer-friendly Version

Interactive Discussion 